\title{
A FOURTH AMENDMENT FRAMEWORK FOR THE FREE EXERCISE CLAUSE
}

\author{
Adam Lamparello* \\ I. INTRODUCTION
}

The Supreme Court's Free Exercise Clause jurisprudence is inconsistent with the clause's original meaning and fails to strike the proper balance among religious liberty claims, equal protection guarantees, and laws advancing important societal interests. ${ }^{1}$ The problem with the Court's decisions is that they have afforded the highest level of constitutional protection for religious liberty regardless of the context within which it is exercised. In so doing, the Court has invalidated generally applicable laws that advance legitimate governmental objectives, do not target particular religions or religious practices, and merely prohibit, rather than compel, conduct that is not, in itself, religious in nature.

This article proposes a paradigm for resolving disputes under the free exercise clause that is analogous to the framework used by the court under the Fourth Amendment when balancing privacy rights against investigatory powers of law enforcement. In its Fourth Amendment jurisprudence, the Court provides varying degrees of protection to privacy - and imposes different evidentiary requirements on law enforcement - depending on the context in which privacy is affected, the intrusiveness of a particular search, and the asserted governmental interests. For example, privacy receives the strongest protections in areas such as the home, thus requiring law enforcement to have probable cause and a warrant before conducting a search (unless an exception to the warrant requirement applies). ${ }^{2}$ In quasi-public spaces, such as a motor vehicle or a place of business, individuals have a reduced expectation of privacy that permits searches based on reasonable suspicion of

* Assistant Professor of Law, Indiana Tech Law School.

1. See U.S. CONST., amend. I ("Congress shall make no law respecting an establishment of religion, or prohibiting the free exercise thereof; or abridging the freedom of speech, or of the press; or the right of the people peaceably to assemble, and to petition the government for a redress of grievances").

2. See Ben Lowry, Subjective Intent and the Police-Created Exigency Doctrine: The Lawlessness of the Lawfulness Test, 51 U. LouISVILLE L. REV. 591, 598 (2013). For example, law enforcement does not need a warrant or probable cause when confronted with exigent circumstances, which one commentator describes as follows:

[T] he Court has recognized that in certain "exigent circumstances," the police may permissibly bypass the warrant requirement. Exigent circumstances have been defined as situations that present a "specially pressing or urgent law enforcement need," or, alternatively, as "situations where 'real immediate and serious consequences' will 'certainly occur' if a police officer postpones action to obtain a warrant." To date, the Court has recognized three sets of circumstances that are sufficiently "exigent" to excuse the police from having to obtain a warrant: (1) when police are in "hot pursuit" of a fleeing suspect, (2) when the safety of police officers or other persons would be jeopardized by delaying to obtain a warrant, and (3) when evidence is likely to be destroyed or otherwise removed. 
unlawful conduct. ${ }^{3}$ In public spaces, such as open fields or sidewalks, citizens have little, if any, expectation of privacy, and law enforcement typically needs no suspicion whatsoever to observe objects that are placed in public view. The Table below summarizes the Court's approach to balancing privacy rights against law enforcement's investigatory powers.

Table I

The Standards for Resolving Fourth Amendment Disputes

\begin{tabular}{|l|l|l|}
\hline Fourth Amendment & Level of Protection & Standard \\
\hline $\begin{array}{l}\text { Private Space (e.g. } \\
\text { private residences) }\end{array}$ & $\begin{array}{l}\text { Categorical/Near } \\
\text { Absolute }\end{array}$ & $\begin{array}{l}\text { Probable cause and a } \\
\text { warrant (absent one of } \\
\text { the exceptions to the } \\
\text { probable cause and } \\
\text { warrant requirements) }\end{array}$ \\
\hline $\begin{array}{l}\text { Quasi-Public Space (e.g. } \\
\text { motor vehicles, schools, } \\
\text { places of business, } \\
\text { libraries) }\end{array}$ & Context-Specific & $\begin{array}{l}\text { Reasonable Suspicion } \\
\text { (no warrant required) }\end{array}$ \\
\hline $\begin{array}{l}\text { Public Space (e.g., open } \\
\text { fields, public sidewalks, } \\
\text { items in plain view) }\end{array}$ & Minimal & $\begin{array}{l}\text { No suspicion or warrant } \\
\text { required }\end{array}$ \\
\hline
\end{tabular}

The Court should adopt a similar framework such that the strength of a free exercise claim could vary depending on where, when, and how it is exercised. Specifically, the validity of a law interfering with religious liberty would depend on whether it:

- Affects religious practices or beliefs;

- Prohibits or compels conduct;

- Directly or indirectly targets religious practices or beliefs;

- Applies in the public or private arena; and

- Advances valid and secular governmental interests.

As the Table below demonstrates, this approach would result in protections for religious liberty that are categorical in some instances and context-specific in others.

3. See, e.g., Terry v. Ohio, 392 U.S. 1 (1968). 


\section{Table II}

The Fourth Amendment Paradigm Applied to the Free Exercise Clause

\begin{tabular}{|l|l|l|}
\hline $\begin{array}{l}\text { Free Exercise } \\
\text { Clause }\end{array}$ & $\begin{array}{l}\text { Level } \\
\text { Protection }\end{array}$ & Standard \\
\hline $\begin{array}{l}\text { Private (e.g., } \\
\text { religious } \\
\text { ceremonies) }\end{array}$ & $\begin{array}{l}\text { Categorical/Near } \\
\text { Absolute }\end{array}$ & $\begin{array}{l}\text { Laws restricting religious practices or } \\
\text { beliefs are presumptively invalid unless } \\
\text { they further a compelling government } \\
\text { interest and are the least restrictive } \\
\text { means available to achieve that interest }\end{array}$ \\
\hline $\begin{array}{l}\text { Quasi-Public } \\
\text { (e.g., some } \\
\text { corporations, } \\
\text { libraries, and } \\
\text { places where } \\
\text { access or } \\
\text { membership } \\
\text { may be } \\
\text { restricted) }\end{array}$ & $\begin{array}{l}\text { Context-Specific } \\
\text { (Reduced) }\end{array}$ & $\begin{array}{l}\text { A law is invalid unless it furthers a } \\
\text { substantial governmental interest and is } \\
\text { the least restrictive means available to } \\
\text { achieve that interest }\end{array}$ \\
\hline $\begin{array}{l}\text { Public (e.g., } \\
\text { businesses } \\
\text { offering } \\
\text { commercial } \\
\text { products and } \\
\text { services } \\
\text { available to } \\
\text { the general } \\
\text { public) }\end{array}$ & Minimal & $\begin{array}{l}\text { Laws are presumptively valid provided } \\
\text { they do not target or disparately impact } \\
\text { particular religions } \\
\text { practices }\end{array}$ \\
\hline
\end{tabular}

Consequently, in the public and, to a slightly lesser extent, quasi-public arena, the right to freely exercise one's religion would not permit citizens to avoid complying with valid laws that do not target particular religions or religious practices. This rule would apply to public and private businesses that provide services or commercial products to the public, corporations that receive federal funding, and organizations, such as libraries, that may restrict access or membership. On the other hand, laws burdening religious practices in private areas would trigger the highest level of protection and require the government to satisfy strict scrutiny. ${ }^{4}$ This

4. See Richard H. Fallon, Jr., Strict Judicial Scrutiny, 54 UCLA L. REv. 1267, 1273 (2007) (In modern constitutional law, the term "strict scrutiny" refers to a test under which statutes will be pronounced unconstitutional unless they are "necessary" or "narrowly tailored" to serve a "compelling governmental interest"). See also Matthew D. Bunker, Clay Calvert, \& William C. Nevin, Strict in Theory, But Feeble in Fact? First Amendment Strict Scrutiny and the Protection of Speech, 16 ComM. L. \& 
approach — based on the Court's Fourth Amendment jurisprudence-would be an effective method by which to strike the proper balance between citizens' right to freely practice their religion and the government's interest in regulating public conduct that affects the health, safety, and welfare of citizens. This includes the right to be free from discriminatory treatment on the basis of ethnicity and sexual orientation.

Put simply, the Free Exercise Clause should be viewed in the broader context of promoting equality and liberty for all citizens. As discussed below, the Framers adopted the Clause to protect all forms of religious worship and to give citizens the liberty to practice their religious beliefs free from governmental coercion. The Free Exercise Clause does not, however, give citizens or businesses that offer goods and services to the general public the right to avoid complying with valid laws on religious grounds, particularly where those laws further the very equality that the Free Exercise Clause protects in religious contexts. This interpretation comports with the historical record and promotes liberty, autonomy, and equality on an individual and societal level. Part II discusses the original meaning and purpose of the Free Exercise Clause as evidenced by the drafting process and eventual adoption in the First Congress. Part III examines the Court's free exercise case law over the last century and concludes that it has resulted in over-protecting religious freedom and undervaluing the important governmental interests underlying many generally applicable laws. Part IV concludes that the tiered framework used in the Fourth Amendment context to balance privacy rights against the needs of law enforcement should be adopted to determine the strength of a free exercise claim in light of countervailing governmental interests.

\section{The Original MEANing of the Free EXercise Clause - The First CONGRESS REJECTED THE IDEA THAT CITIZENS SHOULD RECEIVE EXEMPTIONS FROM GENERALLY APPLICABLE LAWS BASED ON RELIGIOUS BELIEF}

The Free Exercise Clause provides that "Congress shall make no law respecting an establishment of religion or prohibiting the free exercise thereof." record reveals that the drafters of the did not intend for it to grant individuals a right to be exempt from such laws, but instead to prevent the government from discriminating against or disfavoring particular religions or religious practices.

\section{A. Free Exercise and Freedom of Conscience}

On one level, "[t]he record of the drafting of the Free Exercise Clause reads like a markup session, the focus of which was to craft text that was not redundant or stylistically awkward." 6 On another level, the First Congress's substantive deliberations reveal the Clause's intended meaning. In the early stages of the drafting

POL'Y 349, 356-57 (2006).

5. See, U.S. CONST., amend. 1.

6. Vincent Phillip Munoz, The Original Meaning of the Free Exercise Clause: The Evidence from the First Congress, 31 HARV. J.L. \& PUB. POL’Y 1083, 1109 (2008). 
process, James Madison proposed two amendments directed at protecting freedom of religion and conscience. The first, which was directed at the federal government, provided that " $[t]$ he civil rights of none shall be abridged on account of religious belief or worship, nor shall any national religion be established nor shall the full and equal rights of conscience be in any manner, or on any pretext, infringed."7 The second was directed at the states and stated that "[n]o State shall violate the equal rights of conscience, or the freedom of the press, or the trial by jury in criminal case." Subsequent revisions retained language prohibiting the establishment of religion, guaranteeing the free exercise of religion, and protecting equal rights of conscience. ${ }^{9}$ This suggests that the First Congress contemplated an exemption for citizens who objected to a law on the grounds that it violated their religious beliefs. ${ }^{10}$

However, later revisions eliminated any language referring to "equal rights of conscience," 11 and the penultimate revision stated as follows:

Congress shall make no law establishing articles of faith or a mode of worship, or prohibiting the free exercise of religion, or abridging the freedom of speech, or the press, or the right of the people peaceably to assemble, and petition to the government for the redress of grievances. ${ }^{12}$

Admittedly, even though "no member of Congress articulated what he understood by the phrases 'free exercise' or 'rights of conscience, ${ }^{, 13}$ the elimination of the latter phrases, from the Clause indicates that it was not considered a part of the free exercise of religion:

[S]ome members of the House might have thought that these two phrases denoted different types of protection, because they included both phrases in their versions of the amendment. If so, the record does not include their explanations of what the differences were. And if such differences did exist, the Senate may have made the point moot by quickly eliminating the text "rights of conscience." 14

The evolution of what became the Free Exercise Clause suggests that the First Congress neither intended nor expected that a right of conscience would be encompassed within the broader right to freely exercise one's religion. As one scholar explains, the First Congress's deliberations and the final version of the free exercise clause "strongly suggest[s] that the First Congress did not understand the Free Exercise Clause to include a right to religious exemptions from generally

7. Id. at 1102-1103.

8. Id. at 1103 .

9. Id.

10. Id. at 1106-07.

11. Id.

12. Id. at 1108 .

13. Id. at 1109 .

14. Id. 
applicable laws." 15 This Second Amendment's drafting and adoption underscores this point.

\section{B. The Second Amendment's Adoption Clarifies the Meaning of the Free Exercise Clause}

In its initial versions, the Second Amendment exempted religious, or conscientious, objectors from military service. ${ }^{16}$ A proposed amendment provided that "right of the people to keep and bear arms shall not be infringed; a well-armed and well-regulated militia being the best security of a free country: but no person religiously scrupulous of bearing arms shall be compelled to render military service in person." 17 A subsequent amendment qualified this exemption, with one stating "any person religiously scrupulous of bearing arms ought to be exempted, upon payment of an equivalent to employ another to bear arms in his stead." 18

The ensuing debate among members of Congress confirms that the conscientious objector provision was limited in scope. One member argued that it gave the government "discretionary power to " declare who are those religiously scrupulous, and prevent them from bearing arms." 19 The shift against a conscientious objector provision solidified when Representative Egbert Benson moved to eliminate the conscientious objector provision entirely, stating as follows:

No man can claim this indulgence of right. It may be a religious persuasion, but it is no natural right, and therefore ought to be left to the discretion of the Government. If this stands part of the constitution, it will be a question before the Judiciary on every regulation you make with respect to the organization of the militia, whether it comports with this declaration or not. It is extremely injudicious to intermix matters of doubt with fundamentals. ${ }^{20}$

Benson believed that the conscientious objector provision was not "part of the natural right to religious liberty." ${ }^{21}$ Instead, Benson believed that "the rights of conscience could ... be balanced against other competing governmental interests," 22 and that the judiciary and legislative branches would "always possess humanity enough to indulge this class of citizens in a matter they are so desirous of." 23

Some members of the House disagreed with Benson's position, and the division over the conscientious objector provision resulted in a compromise amendment

15. Id. at $1009-10$.

16. Id. at 1110 .

17. Id.

18. Id. at 1111 .

19. Id. at 1112 .

20. Id. at 1113 .

21. Id.

22. Id. at 1114 .

23. Id. at 1113-14. 
stating that "no person religiously scrupulous shall be compelled to bear arms in person." 24 The words "in person" indicate that the state could impose alternative obligations on citizens who received exemptions from particular laws on religious grounds:

$[\mathrm{M}]$ any of those who opposed bearing arms were equally scrupulous of getting substitutes or paying an equivalent. If religious individuals were understood to possess a right not to serve in the military on account of conscientious objection, then for the same reason they also would seem to possess an equal right not to pay for an equivalent. The reinsertion of "in person" suggests that the House understood conscientious objection not to override a citizen's civil obligations. Stated differently, “in person'” indicates that the House thought the state legitimately could demand some actions that burdened religious individuals' consciences. By restoring the words " in person," the House rejected Boudinot's hope that they 'show the world that proper care is taken that the Government may not interfere with the religious sentiments of any person. ${ }^{, 25}$

This discussion was rendered moot in September of 1789 when the First Congress struck the conscientious objector provision altogether, which supports the proposition that "Congress as a whole considered and rejected a constitutional right to exemption based on religion.," 26 Indeed, "[t]he concurrent but separate discussions over exemptions from military service on the one hand, and religious free exercise on the other, suggest that the House did not understand religious free exercise to include exemptions from generally applicable laws."27

To be sure, the meaning of the Free Exercise Clause must be understood in light of the Establishment Clause, which prohibits the government from endorsing or preferring a particular religion or from favoring religion over non-religion. ${ }^{28}$ The Establishment Clause speaks to the relationship between government and its citizens, and reflects the principle that a government-sponsored religion would devalue and implicitly discourage alternative religious beliefs (or practices). ${ }^{29}$ In this way, the

24. Id. at 1115 (emphasis added).

25. Id. at 1115-16 (internal citation omitted) (emphasis added).

26. Id. at 1117 (stating that "Congress did not consider exemption from a generally applicable legal duty to be necessary to protect religious freedom").

27. Id. In addition, "states whose majorities proposed a conscientious objector amendment (Virginia, North Carolina, and Rhode Island) also proposed an amendment that 'all men have an equal, natural, and inalienable right to the free exercise of religion, according to the dictates of conscience." If these states believed that free exercise of religion incorporated a conscientious objector provision, a separate amendment would have been unnecessary. The drafters of the Free Exercise Clause did not likely intend for it to encompass a right "to be exempt from civic obligations on account of their incompatibility with an individual's religious beliefs." Id.

28. See U.S. Const., amend. I.

29. See James A. Campbell, Newdow Calls for a New Day in Establishment Clause Jurisprudence: Justice Thomas's 'Actual Legal Coercion'Standard Provides the Necessary Renovation, 39 AKRON L. REV. 541, 550 (2011). The Founders intended primarily for the Establishment Clause to prevent the federal government from establishing a national religion:

The heart of the Establishment Clause, as expressed by its drafter James Madison, is that the government "should not establish a religion and enforce the legal observation of it by law." The 
Establishment Clause creates a climate free of coercion to enable citizens to express their religious beliefs without the fear of being marginalized or punished. ${ }^{30}$

At the same time, neither the Constitution's text nor the deliberations in the First Congress suggest that the right to freely exercise one's religion permits citizens to avoid complying with generally applicable laws that further legitimate governmental objectives. It certainly does not support the proposition that the government is forbidden from requiring all citizens to comply with valid laws in the public forum regardless of their religious beliefs.

Such an interpretation would allow the Free Exercise Clause to be a vehicle for the type of discrimination that, when applied to religious beliefs, it was designed to prohibit. For example, the state of Indiana's recently passed Religious Freedom Restoration Act ("RFRA") could be interpreted to give corporations offering services the general public, the right to deny service to groups of citizens, such as same-sex couples and Muslims, based on religious belief. ${ }^{31}$ This perverts the original purpose underlying the Free Exercise Clause, which was to protect citizens from the coercive powers of government, not to give citizens that authority to do under the guise of religion what the government cannot do to them. Indeed, given the original purpose underlying the Free Exercise Clause, corporations that discriminate against same-sex couples cannot possibly claim that the government - through anti-discrimination laws or otherwise -is infringing on their free exercise rights, just as individuals who scream "fire" in a crowded theater cannot claim that the government is infringing on their free speech rights. ${ }^{32}$ Rights have limits because liberty is both an individual and collective good.

Additionally, business owners who would refuse services to consumers on the basis of sexual orientation or ethnicity are not actually practicing their religion. They are providing products and products to citizens in the public arena, where government has a powerful interest in ensuring equality and non-discriminatory treatment.

Framers' primary goal in adopting the Establishment Clause was to prevent the oppression associated with a government-established church. Such persecution and maltreatment included mandatory church attendance, taxation for the direct support of a particular religious sect, and punishment of nonbelievers. Inherent in these problems was the government's use of actual legal force, or threat of force, to uphold the power of the established church. Id. (internal citation omitted). 30. See id. at 545-46. One commentator explains as follows:

The history and context of the Founding Era are fundamental in evaluating the meaning of the Establishment Clause. America was founded by refugees escaping Europe's tyrannical religious climate. However, the religious persecution did not end when the colonists reached the New World. Because the British continued to exercise religious dominion over the colonists through the authority of the Church of England, the colonists faced continuing oppression once they settled in America. This religious persecution, at least in part, contributed to the American Revolution. Such turbulent circumstances illustrate why the Framers were hesitant to address "the subject of religion for fear that the discussion might lead to some form of federal ecclesiastical establishment" similar to the Church of England.

31. See Garret Epps, The Atlantic, What Makes Indiana's Religious Freedom Law Different? (Mar. 30, 2015), available at http://www.theatlantic.com/politics/archive/2015/03/what-makes-indianas-religiousfreedom-law-different/388997/.

32. See, e.g., Jessica Ronay, Adults Post the Darndest Things: [Ctrl + Shift] Freedom of Speech [Esc] Our Past, 46 U. TOL. L. REV. 73, 74 (2014) (stating, "[j]ust as courts have held that crying "fire" in a crowded theater is not protected speech, the new world of revenge porn and mug shot profiteering may require similar limitations on speech protected by the First Amendment"). 
Notwithstanding, even if serving a same-sex couple or a Muslim interfered with a corporation's religious beliefs, the interference would be justifiable. In no way does a law prohibiting such discrimination interfere with the corporation's ability to believe whatever it chooses and to practice those beliefs in a number of private and public settings, such as in a church or on a public street. Moreover, just like the individual who chooses to drive on a public road or place items in an open field, citizens who make the decision to serve the public should not expect that their religious beliefs will have the same constitutional protections as they would in a church or synagogue. Of course, this is not to say that business owners' free exercise rights vanish when they decide to open a business. It is to say that the government and societal interest in providing equal treatment and liberty for all citizens should not be trumped by those who voluntarily holds themselves out to the public as providers of goods and services, and who would use their religious beliefs to engage in discriminatory conduct.

Of course, conscientious objections to valid laws can sometimes be permissible, but they should be the exception, not the rule, and function to guarantee a citizen's private right to practice his or her religion. For example, parents should not be required to send their children to public high schools if they have a long-standing religious tradition of homeschooling, ${ }^{33}$ because in this context the government is compelling parents to violate deeply held religious beliefs in a decidedly private realm.

Ultimately, the differences between in exercising religion in the private versus public sphere, between laws that target religious practices or apply equally to all citizens, and between laws compelling as opposed to prohibiting conduct, are among of several factors that the Court should consider to determine the strength of the free exercise right. Generally speaking, absent a compelling government interest, in private areas the government should not be permitted to compel or prohibit conduct that infringes on religious beliefs or practices. ${ }^{34}$ Additionally, laws that target or disproportionately affect specific religions will almost always be invalid. ${ }^{35}$ Conversely, in public and quasi-public areas where goods or services are offered to the general public, protections for religious liberty should be reduced, absent a showing that the law constitutes an extraordinary burden on religious beliefs. In this context, such a claim is furthest removed from the meaning and purpose of the Free Exercise Clause.

Applying this framework, the government would not be able to compel a church to marry same-sex couples, but it may require a judicial officer to perform civil samesex marriages even if those marriages infringe on the officer's religious beliefs. Similarly, as established by the Court in Church of Lukumi Babalu Aye v. Hialeah, ${ }^{36}$ the government may not prohibit a religious group from sacrificing an animal in its

33. See Wisconsin v. Yoder, 406 U.S. 205 (1972) (holding that Wisconsin's compulsory education law violated the free exercise clause as applied to an Amish family).

34. See Church of Babalu Aye v. Hialeah, 508 U.S. 520 (1993) (holding that a law prohibiting ritual animal sacrifice violated the free exercise rights of church members who practices animal sacrifice in connection with their faith).

35. See Fallon, Jr., supra note 4, at 1272.

36. Church of Lukumi Babalu Aye, 508 U.S. at 520. 
place of worship, but it would certainly be able to prohibit this practice during the middle of the day on a busy street. Laws requiring judicial officers to perform civil marriages, and those regulating the time and place of animal slaughter may interfere with religious beliefs, but neither law can be viewed as targeting or disfavoring particular religions (or religious practices), or as advancing interests that favor some religions over others (or religion over non-religion). Of course, the law directed at judicial officers is compulsory, but it applies to the officer in his or her public role, and it treats all officers equally regardless of religious belief. Put simply, to achieve equality in public life citizens must be treated primarily as secular beings. Admittedly, laws that prohibit conduct are indirectly or implicitly compulsive, and the line between laws affecting religious practices as opposed to belief is blurry. Instead of trying to make artificial distinctions between practices and beliefs, the Court should base its distinctions on time, place, and effect. As discussed below, for a substantial period in its history, the Supreme Court adopted a similar approach in free exercise cases, but in recent years the Court has taken a broader view that has divorced the Free Exercise Clause from its historical underpinnings.

\section{THE SUPREME COURT'S FREE EXERCISE JURISPRUDENCE IN LIGHT OF THE History AND MEANING OF THE FREE EXERCISE ClAUSE}

\section{A. Reynolds v. United States - Rejecting a Conscientious Objector Exception}

In Reynolds $v$. United States ${ }^{37}$ the Court held that laws criminalizing polygamy did not infringe on the free exercise of religion. ${ }^{38}$ In so holding, the Court refused to exempt individuals who claimed that their religious beliefs sanctioned polygamous relationships, holding that "[1]aws are made for the government of actions, and while they cannot interfere with mere religious belief and opinions, they may with practices." 39

The Court's decision not only distinguishes between religious beliefs and practices, but it recognizes that law may interfere with religious beliefs. As the Court stated, the Free Exercise Clause is not intended to make "the professed doctrines of religious belief superior to the law of the land, and in effect to permit every citizen to become a law unto himself." ${ }^{40}$ In such a circumstance, the government could exist "in name only." 41

37. Reynolds v. United States, 98 U.S. 145 (1878).

38. Id. at 167 .

39. Id. at 166 (emphasis added). The Court reasoned as follows:

Suppose one believed that human sacrifices were a necessary part of religious worship, would it be seriously contended that the civil government under which he lived could not interfere to prevent a sacrifice? Or if a wife religiously believed it was her duty to burn herself upon the funeral pile of her dead husband, would it be beyond the power of the civil government to prevent her carrying her belief into practice?

40. Id. at 166-67.

41. Id. (stating that "[i]t matters not that his belief was a part of his professed religion: it was still belief, and belief only"). 


\section{B. United States $v$ Ballard - The Veracity of an Individual's Religious Beliefs is Irrelevant}

In United States v. Ballard, ${ }^{42}$ the Court held that juries may not make qualitative judgments concerning a defendant's religious beliefs. ${ }^{43}$ If juries (or courts) were permitted to do so, the right to freely exercise one's religion would mean little, if anything:

Religious experiences which are as real as life to some may be incomprehensible to others. Yet the fact that they may be beyond the ken of mortals does not mean that they can be made suspect before the law ... [i]f one could be sent to jail because a jury in a hostile environment found those teachings false, little indeed would be left of religious freedom. The Fathers of the Constitution were not unaware of the varied and extreme views of religious sects, of the violence of disagreement among them, and of the lack of any one religious creed on which all men would agree. They fashioned a charter of government which envisaged the widest possible toleration of conflicting views. Man's relation to his God was made no concern of the state. He was granted the right to worship as he pleased and to answer to no man for the verity of his religious views. The religious views espoused by respondents might seem incredible, if not preposterous, to most people. But if those doctrines are subject to trial before a jury charged with finding their truth or falsity, then the same can be done with the religious beliefs of any sect. ${ }^{44}$

Indeed, the Free Exercise Clause not only "forestalls compulsion by law of the acceptance of any creed or the practice of any form of worship, ${ }^{45}$ but also "safeguards the free exercise of the chosen form of religion."

42. United States v. Ballard, 322 U.S. 78 (1944).

43. Id. at $86-87$.

44. Id. (explaining that "[t]he law knows no heresy, and is committed to the support of no dogma, the establishment of no sect") (quoting Cantwell, 10 U.S. at 303 (1940)).

45. Cantwell, 10 U.S. at 303.

46. Id.; see also Frazee v. Ill. Security Dep't, 489 U.S. 829 (1989). In Frazee the Court invalidated an Illinois law that denied unemployment benefits to worker who rejected a job offer because job would have required him to work on Sunday. The Court held that the free exercise clause prohibits the government from examining the underlying merits of an individual's free exercise claim:

Our judgments in those cases rested on the fact that each of the claimants had a sincere belief that religion required him or her to refrain from the work in question. Never did we suggest that unless a claimant belongs to a sect that forbids what his job requires, his belief, however sincere, must be deemed a purely personal preference rather than a religious belief. Indeed, in Thomas, there was disagreement among sect members as to whether their religion made it sinful to work in an armaments factory; but we considered this to be an irrelevant issue and hence rejected the State's submission that unless the religion involved formally forbade work on armaments, Thomas' belief did not qualify as a religious belief. Because Thomas unquestionably had a sincere belief that his religion prevented him from doing such work, he was entitled to invoke the protection of the Free Exercise Clause (citing Thomas v. Review Bd. of Indiana Employment Security Div., 450 U.S. 707 (1981); Hobbie v. Unemployment Appeals Comm'n of Florida, 480 U.S. 136 (1987)). 


\section{Cantwell v. Connecticut-Religious Practices are not Given the Same Protections as Religious Beliefs}

In Cantwell v. Connecticut ${ }^{47}$ the Court invalidated a statute that prohibited citizens from soliciting money for a religious, charitable, or philanthropic purpose. ${ }^{48}$ Although the "freedom to adhere to such religious organization or form of worship as the individual may choose cannot be restricted by law,"49 the Court again distinguished between religious beliefs and practices, holding that "[t]he first is absolute but, in the nature of things, the second cannot be." 50

Accordingly, a state may "by general and non-discriminatory legislation regulate the times, the places, and the manner of soliciting upon its streets, and ... may in other respects safeguard the peace, good order and comfort of the community, without unconstitutionally invading the liberties protected by the Fourteenth Amendment. ${ }^{" 51}$ The Court explained as follows:

Even the exercise of religion may be at some slight inconvenience in order that the state may protect its citizens from injury. Without doubt a state may protect its citizens from fraudulent solicitation by requiring a stranger in the community, before permitting him publicly to solicit funds for any purpose, to establish his identity and his authority to act for the cause which he purports to represent. ${ }^{-}$The state is likewise free to regulate the time and manner of solicitation generally, in the interest of public safety, peace, comfort or convenience. ${ }^{52}$

The majority in Cantwell rejected the argument that the law at issue applied equally to all citizens, as it conditioned the right to solicit upon a state official's determination of whether a cause was "religious." 53 Thus, while "[c]onduct remains subject to regulation for the protection of society," religion for disparate treatment.

\section{Sherbert v. Verner-Laws Compelling Conduct and Disproportionately Burdening Religion are Invalid}

In Sherbert v. Verner, ${ }^{55}$ the Court made it more difficult for the government to

47. Cantwell, 10 U.S. at 296.

48. Id. at 307. In Cantwell, the Court incorporated the free exercise clause to the states through the Fourteenth Amendment, holding that the "fundamental concept of liberty embodied in that Amendment embraces the liberties guaranteed by the First Amendment." Id. at 303.

49. Id. at 303-04.

50. $I d$.

51. Id. at 304 .

52. Id. at 306-07.

53. Id. (holding that, "to condition the solicitation of aid for the perpetuation of religious views or systems upon a license, the grant of which rests in the exercise of a determination by state authority as to what is a religious cause, is to . . . burden ... the exercise of liberty protected by the Constitution").

54. Id.

55. 374 U.S. 398 (1963). 
enforce generally applicable laws against religious objectors. The petitioner a member of the Seventh - day Adventist church, did not work on Saturdays, which her church considered a day of rest. ${ }^{56}$ When the petitioner's employer switched from a five to six-day workweek, petitioner refused to work on Saturdays and was fired. ${ }^{57}$ The state subsequently denied employment benefits, and petitioner sued. ${ }^{58}$ The Connecticut Supreme Court upheld the decision, but the Court, in a 7-2 decision, reversed. ${ }^{59}$

Writing for the majority, Justice Brennan began by acknowledging that the Court had upheld laws regulating conduct "prompted by religious beliefs or principles, for 'even when the action is in accord with one's religious convictions, [it] is not totally free from legislative restrictions." ${ }^{" 60}$ However, the circumstances in which the Court has permitted laws to infringe on religious liberty typically involve "some substantial threat to public safety, peace or order." ${ }^{\prime \prime 1}$ Likewise, the state may not "penalize or discriminate against individuals or groups because they hold religious views abhorrent to the authorities." ${ }^{\text {" }}$ Consequently, "“[i]f the purpose or effect of a law is to impede the observance of one or all religions or is to discriminate invidiously between religions, that law is constitutionally invalid even though the burden may be characterized as being only indirect." 63

The most striking aspect in Sherbert was the requirement that laws causing only an "incidental burden on the free exercise of ... religion may be justified by a 'compelling state interest in the regulation of a subject within the State's constitutional power to regulate." "64 Applying this standard, the Court held that the state's asserted interest did not outweigh the substantial burden on the employee's religion: ${ }^{65}$

56. Id. at 399 .

57. Id.

58. Id. at 401 .

59. Id. at 402 .

60. Id. at 403 (quoting Braunfeld v. Brown, 366 U.S. 599, 603 (1961)).

61. Id. (citing Reynolds v. United States, 98 U.S. 145 (1878); Jacobson v. Massachusetts, 197 U.S. 11 (1905); Prince v. Massachusetts, 321 U.S. 158 (1944) (holding that a mother could be prosecuted under a state's child labor laws for using her children to distribute literature in the streets); Cleveland v. United States, 329 U.S. 14 (1946); Torcaso v. Watkins, 367 U.S. 488 (1961); Fowler v. Rhode Island, 345 U.S. 67 (1953)).

62. Id. at 402 .

63. Id. at 404 (quoting Braunfeld, 366 U.S. at 607).

64. Id. at 402-03 (quoting NAACP v. Button, 371 U.S. 415, 438 (1963)).

65. Id. at 407. The Court held that the state's justification for the la-to prevent the filing of fraudulent claims - was not sufficiently compelling:

The appellees suggest no more than a possibility that the filing of fraudulent claims by unscrupulous claimants feigning religious objections to Saturday work might not only dilute the unemployment compensation fund but also hinder the scheduling by employers of necessary Saturday work. But that possibility is not apposite here because no such objection appears to have been made before the South Carolina Supreme Court, and we are unwilling to assess the importance of an asserted state interest without the views of the state court. Nor, if the contention had been made below, would the record appear to sustain it; there is no proof whatever to warrant such fears of malingering or deceit as those which the respondents now advance. Even if consideration of such evidence is not foreclosed by the prohibition against judicial inquiry into the truth or falsity of religious beliefs ... a question as to which we intimate no view since it is not before us-it is highly doubtful whether such evidence would be sufficient to warrant a substantial infringement of religious liberties. 
Here not only is it apparent that appellant's declared ineligibility for benefits derives solely from the practice of her religion, but the pressure upon her to forego that practice is unmistakable. The ruling forces her to choose between following the precepts of her religion and forfeiting benefits, on the one hand, and abandoning one of the precepts of her religion in order to accept work, on the other hand. Governmental imposition of such a choice puts the same kind of burden upon the free exercise of religion as would a fine imposed against appellant for her Saturday worship. ${ }^{66}$

Echoing the Court's holding in Cantwell, Just Brennan stated that "to condition the availability of benefits upon this appellant's willingness to violate a cardinal principle of her religious faith effectively penalizes the free exercise of her constitutional liberties." ${ }^{67}$ To make matters worse, the law, by intent or effect, targeted Seventh-Day Adventists, as South Carolina "expressly saves the Sunday worshipper from having to make the kind of choice which we here hold infringes the Sabbatarian's religious liberty." ${ }^{\circ 8}$ As a practical matter, therefore, the law substantially burdened, and had a disparate impact upon, the petitioner's religion.

\section{E. Wisconsin v. Yoder-Affirming the Principle that Compelled Conduct Enhances The Severity of the Burden on Religion}

In Wisconsin v. Yoder ${ }^{69}$ an Amish family challenged a statute requiring all children to attend public schools until the age of sixteen. ${ }^{70}$ The family argued, among other things, that the law interfered with basic tenets of their religion, which focused on 'informal learning-through-doing; a life of 'goodness,' rather than a life of intellect; wisdom, rather than technical knowledge, community welfare, rather than competition; and separation from, rather than integration with, contemporary worldly society." 71

The Court agreed, holding that the compulsory education law materially interfered with the Amish family's their values and customs. ${ }^{72}$ As the Court explained, " $[t]$ he impact of the compulsory-attendance law on respondents' practice ... is not only severe, but inescapable, for the Wisconsin law affirmatively compels them, under threat of criminal sanction, to perform acts undeniably at odds

\footnotetext{
66. Id. at 404 .

67. Id. at 406 .

68. Id.

69. Wisconsin, 406 U.S. 205 (1972).

70. Id. at 207.

71. Id. at 211.

72. Id. at 219 (noting that "the unchallenged testimony of acknowledged experts . . almost 300 years of consistent practice, and strong evidence of a sustained faith pervading and regulating respondents' entire mode of life support the claim that enforcement of the State's requirement of compulsory formal education after the eighth grade would gravely endanger if not destroy the free exercise of respondents' religious beliefs").
} 
with fundamental tenets of their religious beliefs."73 The Court highlighted the unique nature of the Amish way of life, which emphasized simplicity and an agrarian lifestyle:

A related feature of Old Order Amish communities is their devotion to a life in harmony with nature and the soil, as exemplified by the simple life of the early Christian era that continued in America during much of our early national life. Amish beliefs require members of the community to make their living by farming or closely related activities. Broadly speaking, the Old Order Amish religion pervades and determines the entire mode of life of its adherents ... Amish objection to formal education beyond the eighth grade is firmly grounded in these central religious concepts. They object to the high school, and higher education generally, because the values they teach are in marked variance with Amish values and the Amish way of life; they view secondary school education as an impermissible exposure of their children to a "worldy" influence in conflict with their beliefs. The high school tends to emphasize intellectual and scientific accomplishments, self-distinction, competitiveness, worldly success, and social life with other students. ${ }^{74}$

Based on these principles, the Court rejected the state's contention that the law was valid because it applied to all citizens, holding that facially neutral laws may nonetheless disproportionately burden particular religions and therefore violate the Free Exercise Clause." 75

\section{F. Goldman v. Weinberger-Context Matters in assessing the Strength of a Free Exercise Claim}

In Goldman v. Weinberger, ${ }^{76}$ the Court acknowledged the role of context in upholding a military regulation that prevented members of the Jewish faith from wearing a yarmulke. ${ }^{77}$ The Court began by explaining that its review of military

73. Id. at 218 .

74. Id. at 210-11. The Court emphasized that the law offended a core component of the free exercise clause because it forced the Amish to conform to a way of life that directly contradicted their religious belief:

Nor is the impact of the compulsory-attendance law confined to grave interference with important

Amish religious tenets from a subjective point of view. It carries with it precisely the kind of objective danger to the free exercise of religion that the First Amendment was designed to prevent. As the record shows, compulsory school attendance to age 16 for Amish children carries with it a very real threat of undermining the Amish community and religious practice as they exist today; they must either abandon belief and be assimilated into society at large, or be forced to migrate to some other and more tolerant region. Id. at 218.

75. Church of Lukumi Babalu Aye, 508 U.S. at 565 (Souter, J., concurring) (quoting Thomas, 450 U.S. at $\underline{717)}$

(quoting Yoder, 406 U.S. at 220) (noting that "a regulation neutral on its face may, in its application, nonetheless offend the constitutional requirement for governmental neutrality if it unduly burdens the free exercise of religion").

76. 475 U.S. 503 (1986)

77. Id. at 504 . 
regulations "is far more deferential than constitutional review of similar laws ... designed for civilian society," as the military "need not encourage debate or tolerate protest to the extent ... required of the civilian state by the First Amendment."78 Specifically, military service requires "the subordination of the desires and interests of the individual to the needs of the service," $" 79$ which includes conforming to military rules and promoting unity among service members. Although the Court's holding was limited to the military, it stands, at least in part, for the proposition that the strength of a Free Exercise Clause claim depends on the context in which it is asserted, and on the competing governmental interests.

\section{G. Lyng v. Northwest Cemetery Prot. Ass'n-The Government's Burden is Reduced When Laws Interfere with Religious Practices on Public Lands}

In Lyng v. Northwest Cemetery Protestors' Association, ${ }^{80}$ Court upheld a state law that permitted timber harvesting and road construction in areas of a national forest that were used for religious purposes by Indiana tribes. ${ }^{81}$ The Court afforded less weight to the free exercise claim in part because the tribes were not "coerced by the Government's action into violating their religious beliefs," and the law did not "penalize religious activity by denying any person an equal share of the rights, benefits, and privileges enjoyed by other citizens." 82

Furthermore, and in sharp contrast to Sherbert, the Court was not swayed by the fact that "the challenged Government action would interfere significantly with private persons' ability to pursue spiritual fulfillment according to their own religious beliefs." ${ }^{, 3}$ Although "indirect coercion or penalties on the free exercise of religion ... are subject to scrutiny," laws that "may make it more difficult to practice certain religions but which have no tendency to coerce individuals into acting contrary to their religious beliefs," do not require a compelling state interest for "otherwise lawful actions." 84 The Court explained as follows:

The Free Exercise Clause simply cannot be understood to require the Government to conduct its own internal affairs in ways that comport with the religious beliefs of particular citizens ... The Free Exercise Clause affords an individual protection from certain forms of governmental compulsion; it does not afford an individual a right to dictate the conduct of the Government's internal procedures. ${ }^{85}$

78. Id. at 507 (citing Chappell v. Wallace, 462 U.S., 296, 300 (1983); Greer v. Spock, 424 U.S. 828, 843844 (1976) (Powell, J., concurring); Parker v. Levy, 417 U.S. 733, 744 (1974)).

79. $I d$.

80. 485 U.S. 439 (1988).

81. Id. at 442 .

82. Id. at 449 .

83. Id.

84. Id. at 450-51.

85. Id. (quoting Bowen v. Roy, 476 U.S. 693 , 699-700 (1986)). 
This reflected the principle that "the Free Exercise Clause is written in terms of what the government cannot do to the individual, not in terms of what the individual can exact from the government." 86 Moreover, the clause "must apply to all citizens alike, and it can give to none of them a veto over public programs that do not prohibit the free exercise of religion. $" 87$ Also, unlike Sherbert, which disproportionately penalized members of one religion, and Yoder, which compelled Amish parents to act contrary to their religious faith, the law in question merely regulated the time and place in which all religions could express their faith.

\section{H. Employment Div. of Oregon v. Smith-Generally Applicable Are Valid Despite Modest Interference with Religious Liberty}

In Employment Division of Oregon v. Smith, ${ }^{88}$ the Court upheld an Oregon law prohibiting the use of peyote against the claim of a religious group that used Peyote in their religious ceremonies. ${ }^{89}$ Writing for the majority, Justice Scalia held that generally applicable laws do not violate the Free Exercise Clause simply because they burden religious practices. ${ }^{90}$ Justice Scalia also noted that the Court has "never held that an individual's religious beliefs excuse him from compliance with an otherwise valid law prohibiting conduct that the State is free to regulate." ${ }^{.91}$ Indeed, "mere possession of religious convictions which contradict the relevant concerns of a political society does not relieve the citizen from the discharge of political responsibilities." 92 Relying on decades of precedent, Justice Scalia explained that "conscientious scruples have not, in the course of the long struggle for religious toleration, relieved the individual from obedience to a general law not aimed at the promotion or restriction of religious beliefs. $" 93$

Put differently, religious beliefs do not permit citizens to avoid complying with a "valid and neutral law of general applicability on the ground that the law proscribes (or prescribes) conduct that his religion prescribes (or proscribes)." ${ }^{94}$ Justice Scalia

86. Id. at 451 (quoting Sherbert, 374 U.S. at 412) (Douglas, J., concurring).

87. Id. at 452. The Court stated as follows:

However much we might wish that it were otherwise, government simply could not operate if it were required to satisfy every citizen's religious needs and desires. A broad range of government activities - from social welfare programs to foreign aid to conservation projects - will always be considered essential to the spiritual well-being of some citizens, often on the basis of sincerely held religious beliefs. Others will find the very same activities deeply offensive, and perhaps incompatible with their own search for spiritual fulfillment and with the tenets of their religion ... The Constitution does not, and courts cannot, offer to reconcile the various competing demands on government, many of them rooted in sincere religious belief, that inevitably arise in so diverse a society as ours. Id.

88. 494 U.S. 872 (1990).

89. Id. at 874 .

90. Id. at $878-89$.

91. Id. at $878-79$

92. Id. at 879 (quoting Minersville Sch. Dist. v. Gobitis, 310 U.S. 586, 594-595 (1940)).

93. Id.

94. Id. at 879 (quoting United States v. Lee, 455 U.S. 252, 263 (1982)) (Stevens, J., concurring); see also Carol Kaplan, The Devil is in the Details: Neutral, Generally Applicable Laws and Exceptions From Smith, 75 N.Y.U. L. REV. 1045, 1058 (2000). Professor Kaplan states as follows:

Smith thus paved the way for a paradigmatic shift in the legal and academic discourse about religious 
noted that the only cases providing exemptions from generally applicable laws "have involved not the Free Exercise Clause alone, but the Free Exercise Clause in conjunction with other constitutional protections, such as freedom of speech and of the press." 95 To be sure, Justice Scalia did not conclude that religious exemptions from generally applicable laws were prohibited, and conceded that they may be desired. ${ }^{96}$ The point was simply that such exemptions are not required, and the situations in which they should be created was an issue better suited to legislatures, not courts. ${ }^{97}$

\section{Church of Lukumi Babalu Aye v. Hialeah - Laws May Not Target Specific Religions or Religious Practices}

In Church of Lukumi Babalu v. City of Hialeah, ${ }^{98}$ the Court re-affirmed the general principle that states may not, by design or effect, target specific religions or religious practices. The ordinance at issue was generally applicable on its face, as it banned the "unnecessar[y]" killing of an animal in a public or private ritual or ceremony not for the primary purpose of food consumption. ${ }^{99}$ The petitioners, a church practicing the Santeria faith, brought suit claiming that the law infringed on its practice of ritual animal sacrifice, and thus disproportionately burdened its free

exercise. Whether intentionally or not, Smith has confounded traditional ways of thinking about religion in society, exposing the need for a jurisprudence that equalizes the liberty interests between majority and minority religious groups, and between religious and secular groups and individuals.

95. Id. at 881 (citing Murdock v. Pennsylvania, 319 U.S. 105 (1943) (invalidating a flat tax on solicitation as applied to the dissemination of religious ideas); Follett v. McCormick, 321 U.S. 573 (1944) (same); Pierce v. Society of Sisters, 268 U.S. 510 (1925) (parents have a fundamental right to direct the upbringing of children); Wooley v. Maynard, 430 U.S. 705 (1977) (invalidating compelled display of a license plate slogan that offended individual religious beliefs); West Virginia Bd. of Education v. Barnette, 319 U.S. 624 (1943) (invalidating a compulsory flag salute statute); see also Roberts v. United States Jaycees, 468 U.S. 609, 622 (1984) (“An individual's freedom to speak, to worship, and to petition the government for the redress of grievances could not be vigorously protected from interference by the State [if] a correlative freedom to engage in group effort toward those ends were not also guaranteed").

96. Id. at 890 .

97. Id.; see also Catholic Charities of Sacramento, Inc. v. Superior Court, 85 P.3d 67, 93 (Cal. 2004) ("We are unaware of any decision in which ... [the U.S. Supreme Court] has exempted a religious objector from the operation of a neutral, generally applicable law despite the recognition that the requested exemption would detrimentally affect the rights of third parties"). In Smith, Justice Scalia stated as follows:

Values that are protected against government interference through enshrinement in the Bill of Rights are not thereby banished from the political process. Just as a society that believes in the negative protection accorded to the press by the First Amendment is likely to enact laws that affirmatively foster the dissemination of the printed word, so also a society that believes in the negative protection accorded to religious belief can be expected to be solicitous of that value in its legislation as well. It is therefore not surprising that a number of States have made an exception to their drug laws for sacramental peyote use... But to say that a nondiscriminatory religious-practice exemption is permitted, or even that it is desirable, is not to say that it is constitutionally required, and that the appropriate occasions for its creation can be discerned by the courts. It may fairly be said that leaving accommodation to the political process will place at a relative disadvantage those religious practices that are not widely engaged in; but that unavoidable consequence of democratic government must be preferred to a system in which each conscience is a law unto itself or in which judges weigh the social importance of all laws against the centrality of all religious beliefs. 494 U.S. at 890.

98. 508 U.S. at 520.

99. Id. at 527. 
exercise rights. ${ }^{100}$

The Court agreed and began its analysis by reaffirming Smith and the principle that a law "need not be justified by a compelling governmental interest even if the law has the incidental effect of burdening a particular religious practice." ${ }^{101}$ By the same token, "if the object of a law is to infringe upon or restrict practices because of their religious motivation, the law is not neutral ... and it is invalid unless it is justified by a compelling interest and is narrowly tailored to advance that interest."102

Applying these principles, the Court held that the ordinance impermissibly burdened the petitioners' religious liberty. To begin with, the record revealed that a primary objective of the ordinance was "suppression of the central element of the Santeria worship service." "103 For example, the inclusion of the words "sacrifice" and "ritual" in the ordinance suggested that it targeted the petitioners' religion. ${ }^{104}$ Moreover, the resolution adopting the ordinance included language referring to concerns by the community that "certain religions may propose to engage in practices which are inconsistent with public morals, peace or safety." 105 Thus, the record revealed an improper "attempt to target petitioners and their religious practices"106 and thereby to achieve a "religious gerrymander." 107 Writing for the majority, Justice Kennedy underscored the effects of the ordinance on the petitioners' religious practices:

The net result of the gerrymander is that few if any killings of animals are prohibited other than Santeria sacrifice, which is proscribed because it occurs during a ritual or ceremony and its primary purpose is to make an offering to the orishas, not food consumption. Indeed, careful drafting ensured that, although Santeria sacrifice is prohibited, killings that are no more necessary or humane in almost all other circumstances are unpunished. ${ }^{108}$

As a result, the ordinance violated the well-settled rule that "[1]egislators may not devise mechanisms, overt or disguised, designed to persecute or oppress a religion or its practices." 109

100. Id. at 520 .

101. Id. at 531 .

102. Id. at 533 .

103. Id. at 534 .

104. Id.

105. Id. at 535 .

106. $I d$.

107. Id. (quoting Walz v. Tax Comm'n of New York City, 397 U.S., 664, 696 (1970)) (Harlan, J., concurring).

108. Id. at 536 .

109. Id. at 547. In its holding, the Court noted that, "[a]lthough the practice of animal sacrifice may seem abhorrent to some, religious beliefs need not be acceptable, logical, consistent, or comprehensible to others in order to merit First Amendment protection." Moreover, "[g]iven the historical association between animal sacrifice and religious worship ... petitioners' assertion that animal sacrifice is an integral part of their religion "cannot be deemed bizarre or incredible," but rather a sincere expression of their religious beliefs. Id. at 531. 


\section{J. City of Boerne v. Flores - Confining the Scope of Federal Power}

City of Boerne v. Flores ${ }^{110}$ is significant because, after the Court's ruling in Smith, Congress enacted RFRA, which effectively re-instated the Sherbert standard and provided greater protections for religious liberty. Under RFRA, laws that substantially burden the free exercise of religion must be justified by a compelling interest and narrowly tailored to achieve that interest "even if the burden results from a rule of general applicability." "111

In City of Boerne, the Court addressed whether Congress could apply RFRA to the states through Section Five of the Fourteenth Amendment. In a 6-3 decision, the Court answered in the negative, holding that Section Five gives Congress 'the power 'to enforce,' not the power to determine what constitutes a constitutional violation." "112 By increasing the government's burden concerning laws impacting religious practices, RFRA altered, not merely enforced, the meaning of the Free Exercise Clause. Put differently, "Congress does not enforce a constitutional right by changing what the right is."113 To be sure, the Court's decision should not be read to suggest that RFRA is unconstitutional. In Gonzales v. $O$ Centro Espirita Beneficente Uniao do Vegetal, ${ }^{114}$ the Court relied on RFRA to hold that the Government's seizure of a sacramental tea containing a banned Schedule I drug violated the free exercise clause. ${ }^{115}$ Additionally, in response to the Boerne ruling, Congress enacted the Religious Land Use and Institutionalized Persons Act (RLUIPA), which provides enhanced protections for religious landowners and therefore indirectly protects citizens from some state laws that substantially burden religion. ${ }^{116}$

\section{K. Locke v Davey - States May Disfavor Religious Practices}

In Locke v. Davey, ${ }^{117}$ the Court held that disfavoring religious practices does not amount to impermissibly targeting a specific religion (or religion generally). In a 72 decision, the Court upheld a law that prohibited citizens from receiving state financial aid for the purpose of pursuing a degree in theology. ${ }^{118}$ Writing for the majority, Chief Justice Rehnquist explained that nothing in the law "suggests animus

110. 521 U.S. 507 (1997)

111. 42 U.S.C.A. $\$ 2000 \mathrm{bb}-1$ (West 2015).

112. Id.; see also City of Boerne, 521 U.S. at 519; see also U.S. Const. amend. XIV, § 5 ("The Congress shall have the power to enforce, by appropriate legislation, the provisions of this article").

113. Id. at 519-20 (holding that the "line between measures that remedy or prevent unconstitutional actions and measures that make a substantive change" depends on whether there is "congruence and proportionality between the injury to be prevented or remedied and the means adopted to that end").

114. 546 U.S. $\underline{418}$ (2006).

115. Id. at 439 (holding that the courts below did not err in determining that the Government failed to demonstrate, at the preliminary injunction stage, a compelling interest in barring the UDV's sacramental use of hoasca).

116. See 42 U.S.C. $\$ \S 2000 \mathrm{cc}$, et seq.

117. 540 U.S. 712 (2004).

118. Id. at 720 . 
toward religion," 119 as the funding exclusion placed "a relatively minor burden" 120 on the petitioner's religious practices. Justice Roberts noted that "[ $t]$ he State's disfavor of religion (if it can be called that) ... imposes neither criminal nor civil sanctions on any type of religious service or rite... does not deny to ministers the right to participate in the political affairs of the community ... [a]nd it does not require students to choose between their religious beliefs and receiving a government benefit." 121 Accordingly, the petitioners' religion was not "singled out ... for unfavorable treatment,"122 and did not exhibit the type of "hostility toward religion which was manifest in Lukumi.

\section{Burwell v. Hobby Lobby - Requiring States to Employ the Least Restrictive Means When Compelling conduct that Burdens Religious Liberty}

In Burwell v. Hobby Lobby, ${ }^{124}$ the Court granted a for-profit corporation an exemption from a provision in the Affordable Care Act requiring corporations to provide health insurance coverage for twenty FDA-approved contraceptive methods. ${ }^{125}$ Several of these methods prevented contraception by blocking a fertilized egg from attaching to the uterus. ${ }^{126}$ The petitioners, who were members of several closely held corporations, argued that the coverage was sufficiently connected to the destruction of an embryo to constitute a violation of their religious beliefs. ${ }^{127}$

The Court agreed and held that the law as applied to the corporations violated RFRA and the Free Exercise Clause. ${ }^{128}$ Writing for the majority, Justice Alito concluded that a law compelling citizens to provide health insurance coverage for contraceptive methods in violation of their religious beliefs constituted a substantial burden upon religion. ${ }^{129}$ Specifically, the law implicated "a difficult and important question of religion and moral philosophy, namely, the circumstances under which it is wrong for a person to perform an act that is innocent in itself but that has the effect of enabling or facilitating the commission of an immoral act by another."130 At the same time, as Justice Alito acknowledged, the goal of guaranteeing cost-free

119. Id. at 725 .

120. Id.

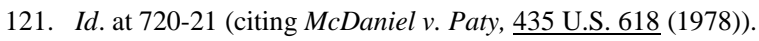

122. Id. at 718,724 .

123. Id. at 724 .

124. 134 S. Ct. 2751 (2014).

125. $I d$.

126. $I d$.

127. Id. at 2778 (citing Smith, 494 U.S. at 887) (“[r]epeatedly and in many different contexts, we have warned that courts must not presume to determine ... the plausibility of a religious claim"); Hernandez $v$. Commissioner, 490 U.S. 680, 699 (1989); Presbyterian Church in U.S. v. Mary Elizabeth Blue Hull Memorial Presbyterian Church, 393 U.S. 440, 450 (1969)).

128. Id. at 2785 .

129. Id. at 2777 (rejecting the contention that "the connection between what the objecting parties must do (provide health-insurance coverage for four methods of contraception that may operate after the fertilization of an egg) and the end that they find to be morally wrong (destruction of an embryo) is simply too attenuated").

130. Id. at 2778 . 
access to the four challenged contraceptive methods was a compelling governmental interest. $^{131}$

However, Justice Alito avoided balancing the free exercise claim against the government's interest because the law was not the least restrictive means to achieve the government's objective. In fact, the government had already established less restrictive rules that could have been equally as effective if applied to the contraception provision. ${ }^{132}$ If, for example, an organization certifies that it opposes offering health insurance coverage for particular methods of contraception, the "organization's insurance issuer or third-party administrator must '[e]xpressly exclude contraceptive coverage from the group health insurance coverage provided in connection with the group health plan." ${ }^{\prime 13}$ In such an instance, the insurance issuer pays separately for any covered contraceptive services, without imposing "any cost-sharing requirements ... on the eligible organization, the group health plan, or plan participants or beneficiaries." "134 Thus, female employees would retain their contraceptive coverage without any additional administrative burdens and organizations would not be forced to participate in a practice that violated their religious beliefs. ${ }^{135}$

Justice Alito's reasoning suggests that Burwell does not significantly expand free exercise rights. Furthermore, Justice Alito intimated that, if the alternative accommodation were applied, petitioners' would not have been able to successfully argue that "providing insurance coverage for the contraceptives at issue ... violates their religion." 136 Perhaps most importantly, Justice Alito emphasized the narrowness of the Court's decision:

We do not hold, as the principal dissent alleges, that for-profit corporations and other commercial enterprises can "opt out of any law (saving only tax laws) they judge incompatible with their sincerely held religious beliefs" . . . Nor do we hold, as the dissent implies, that such corporations have free rein to take steps that impose "disadvantages ... on others" or that require "the general public [to] pick up the tab" ... And we certainly do not hold or suggest that "RFRA demands accommodation of a for-profit corporation's religious beliefs no matter the impact that accommodation may have on ... thousands of women employed by Hobby Lobby."

As Justice Alito stated, the decision "should not be understood to hold that an insurance-coverage mandate must necessarily fall if it conflicts with an employer's religious beliefs."137

The cases above underscore the common themes underlying the Court's jurisprudence, some of which focus on whether a law targets or disproportionately

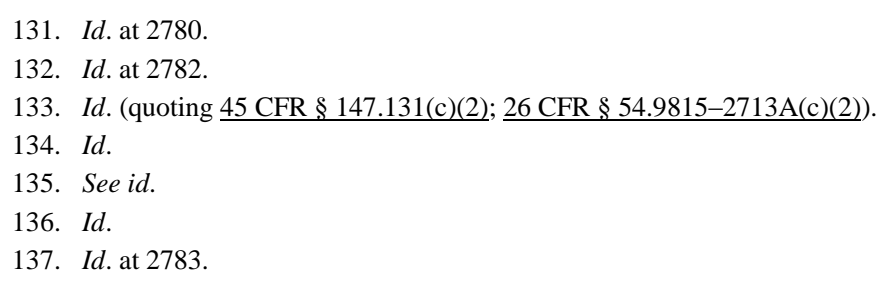


impacts a particular religion and others that assess the severity of the interference with religious liberty. The case-by-case approach taken by the Court has resulted in an unpredictable and largely unprincipled free exercise jurisprudence that has failed to strike the proper balance between religious freedom and the government's interest in promoting the public health, safety, and welfare. The contrary outcomes and starkly different rationales employed in Sherbert and Smith underscore the Court's struggle to create a workable standard in free exercise cases. The effect, among others, is that the Court's decisions have not provided meaningful guidance to lower federal courts, state and federal legislatures, and citizens concerning the scope and meaning of the free exercise clause. As discussed below, the problem is that the Court's decisions are inconsistent with the clause's purpose and original meaning.

\section{A FOURTH AMENDMENT PARADIGM THAT EVALUATES FREE EXERCISE OF RELIGION CLAIMS BASED ON SOCIETAL, NOT MERELY INDIVIDUAL, EXPECTATIONS}

The Court's free exercise case law affords the highest level of protection to religious liberty, regardless of the context. The problem with is that, if a right is given such heightened protections in all circumstances, then whatever balancing test the Court conducts will disproportionately favor religious liberty because the burden on the government in all circumstances will be artificially high. As a result, governmental interests that further important societal objectives, and that would be upheld under less exacting scrutiny, may be deemed insufficient to justify any regulation of religious practices. Put differently, a balancing test is not effective if the weight given to an asserted right is so disproportionate that only the most compelling governmental interests will sustain laws that impact religious liberty. A context-based interpretation would recognize that the right to freely exercise one's religion - like the right to privacy - depends on the circumstances, particularly where the assertion of that right impacts the personal liberties of other citizens.

\section{A. The Assertion of a Constitutionally-Protected Right Must Be Objectively Reasonable}

The protections afforded to free exercise rights should not depend merely on balancing the individual's free exercise rights against governmental interests, but on a societal expectation about what is-and should be-considered objectively reasonable under the circumstances. In recent years, the Court's free exercise jurisprudence has focused solely on the individual's subjective expectations about religious freedom, and not on whether the exercise of this freedom is objectively reasonable. To be clear, this does not mean that the sincerity or veracity of a citizen's religious beliefs should be called into question. It means that the Court should consider whether society would deem the exercise of those beliefs reasonable based on the time and manner in which it is exercised, and the government's interest in protecting public health and welfare.

This is precisely the approach the Court takes when resolving Fourth Amendment disputes, as it considers whether citizens "have a subjective expectation 
of privacy that society is prepared to recognize as reasonable." ${ }^{138}$ Specifically, "[w]hat is reasonable... "depends on all of the circumstances surrounding the search or seizure and the nature of the search or seizure itself." 139 In Skinner v. Railway Labor Executives' Ass' $n,{ }^{140}$ the Court relied on factors such as "the intention of the Framers of the Fourth Amendment ... the uses to which the individual has put a location ... and our societal understanding that certain areas deserve the most scrupulous protection from government invasion."141 These considerations are "equally relevant to determining whether the government's intrusion upon open fields without a warrant or probable cause violates reasonable expectations of privacy and is therefore a search proscribed by the Amendment." ${ }^{142}$ As the Court has noted, "reasonableness is still the ultimate standard"143 and requires a "careful balancing of governmental and private interests." 144

In performing this balancing, the Court has developed a three-tiered approach that conditions the strength of privacy right on the situation in which it is asserted. In Vernonia School District $47 J$ v. Acton, ${ }^{145}$ the Court stated as follows:

What expectations are legitimate varies, of course, with context... depending, for example, upon whether the individual asserting the privacy interest is at home, at work, in a car, or in a public park. In addition, the legitimacy of certain privacy expectations vis-à-vis the State may depend upon the individual's legal relationship with the State... [A]lthough a "probationer's home, like anyone else's, is protected by the Fourth Amendmen[t]," the supervisory relationship between probationer and State justifies "a degree of impingement upon [a probationer's] privacy that would not be constitutional if applied to the public at large." 146

Put simply, "the home does not serve as a bastion of privacy protection that secures privacy in other contexts." 147 As discussed below, the Court's approach not only accounts for competing societal interests, but it reflects the original purposes and meaning of the Fourth Amendment. ${ }^{148}$

138. See Oliver v. United States, 466 U.S. 170, 178 (1984) (holding the "[Fourth] Amendment does not protect the merely subjective expectation of privacy, but only those expectation[s] that society is prepared to recognize as 'reasonable"') (quoting Katz v. United States, 389 U.S.347, 361 (1967)) (emphasis added).

139. Skinner v. Railway Labor Executives' Ass'n, 489 U.S. 602, 619 (1989) (quoting United States v. Montoya de Hernandez, 473 U.S. 531, 537 (1985)).

140. Id.

141. Id.

142. $I d$.

143. Soldal v. Cook County, Ill., 506 U.S. 56, 71 (1992) (quoting Camera v. Municipal Court of City and County of San Francisco, 387 U.S. 523, 539 (1967)).

144. New Jersey v. T.L.O., 469 U.S. 325, 351 (1985) (Blackmun, J., concurring) (upholding a search of student's property by school officials).

145. 515 U.S. 646 (1995).

146. Id. at 654 (citation omitted).

147. Stephanie M. Stern, The Inviolate Home: Housing Exceptionalism in the Fourth Amendment, 95 CORNELL L. REV. 905, 921-22 (2010).

148. See, e.g., Lawrence Rosenthal, Binary Searches and the Central Meaning of the Fourth Amendment, 22 WM. \& MARY BiLl RTS. J. 881, 938-39 (2014). Professor Rosenthal explains that the Fourth Amendment is 


\section{Private Areas - The Highest Degree of Fourth Amendment Protection}

Privacy rights receive the highest level of protection in the home, thus prohibiting law enforcement from performing searches without probable cause and a warrant. In Oliver v. United States, ${ }^{149}$ the Court justified this approach in light of the original purposes of the Fourth Amendment:

The Amendment reflects the recognition of the Framers that certain enclaves should be free from arbitrary government interference. For example, the Court since the enactment of the Fourth Amendment has stressed "the overriding respect for the sanctity of the home that has been embedded in our traditions since the origins of the Republic."

Notwithstanding, the Court has created several exceptions that, even in a private residence, will permit law enforcement to conduct a warrantless search. ${ }^{151}$

\section{Quasi-Public Places—Reduced Evidentiary Burdens on Law Enforcement}

In quasi-public spaces, the Court provides only modest protections for privacy rights while simultaneously reducing the evidentiary burden on law enforcement. In motor vehicles, for example, individuals may be stopped - and subject to a limited search - if officers have reasonable suspicion that the motorist is engaged in criminal conduct. ${ }^{152}$ As the Court stated in New York v. Class, ${ }^{153}$ "[b]ecause vehicles are mobile and subject to pervasive government regulation, an individual's justifiable expectation of privacy in a vehicle is less than in his home."154

The same holds true in other quasi-public areas, such as an individual's place of employment. The Court has held that "the privacy interests of government employees in their place of work which, while not insubstantial, are far less than those found at home or in some other contexts." 155 Thus, when a search is conducted by a governmental employer "for a noninvestigatory, work-related purpos[e] or for the investigatio[n] of work-related misconduct, a government employer's warrantless

grounded in a pragmatic that balancing the right to privacy against competing governmental interests:

Justice Jackson was one of our greatest legal pragmatists, and yet it was he who wrote that Fourth Amendment rights "are not mere second-class rights but belong in the catalog of indispensable freedoms." Indeed, many pragmatists argue that high value should be placed on any number of liberty interests that are compromised by search and seizure. Thus, although some may criticize Fourth Amendment pragmatism as undervaluing liberty interests, nothing inherent to legal pragmatism requires that liberty interests receive less than their due. One can embrace pragmatism without denigrating the importance of the liberty interests protected by the Fourth Amendment when striking a balance between liberty and order (citation omitted).

149. 466 U.S. 170 (1984).

150. Id. at 178 (quoting Payton v. New York, 445 U.S. 573, 601 (1980)) (citing Silverman v. United States, 365 U.S. 505, 511 (1961); United States v. United States District Court, 407 U.S. 297, 313 (1972)).

151. See Lowry, supra note 2, at 598.

152. See, e.g., Terry, 392 U.S. 1.

153. 475 U.S. 106, 124 (1986).

154. $I d$.

155. O'Connor v. Ortega, 480 U.S. 709, 725 (1987). 
search is reasonable if it is justified at its inception and if the measures adopted are reasonably related to the objectives of the search and not excessively intrusive in light of' the circumstances giving rise to the search." ${ }^{156}$ Likewise, public school children and student athletes have reduced privacy interests based in part on the fact that the warrant and probable cause requirements "would unduly interfere with the maintenance of the swift and informal disciplinary procedures," substantial need of teachers and administrators for freedom to maintain order in the schools." $" 158$

\section{Public Areas - No Privacy Protection}

In public areas, citizens have little, if any, Fourth Amendment protection. Thus, "an individual may not legitimately demand privacy for activities conducted out of doors in fields, except in the area immediately surrounding the home." ${ }^{.159}$ In Oliver, the Court held that such areas did not trigger Fourth Amendment protections or give rise to an objectively reasonable expectation of privacy. Specifically, open fields "do not provide the setting for those intimate activities that the Amendment is intended to shelter from government interference or surveillance." ${ }^{160}$ Moreover, "[t]here is no societal interest in protecting the privacy of those activities, such as the cultivation of crops, that occur in open fields," 161 as they are "accessible to the public and the police in ways that a home, an office, or commercial structure would not be."162 Put simply, Fourth Amendment protections only apply to conduct that significantly intrudes upon an individual's privacy. ${ }^{163}$

\section{B. Importing the Fourth Amendment Framework into Free Exercise Jurisprudence}

The Court's Fourth Amendment case law the pragmatic view that "privacy is not a discrete commodity, possessed absolutely or not at all"164 When interpreting

156. City of Ontario, Cal. v. Quon, 560 U.S. 746, 761 (2010) (quoting O'Connor, 480 U.S. 725-26) (citation omitted) (brackets in original).

157. Vernonia Sch. Dist. 47J v. Acton, 515 U.S. 646, 653 (1995) (quoting T.L.O., 469 U.S. at 340).

158. Id. In Vernonia, the Court emphasized the contextual nature of privacy rights:

Legitimate privacy expectations are even less with regard to student athletes. School sports are not for the bashful. They require "suiting up" before each practice or event, and showering and changing afterwards. Public school locker rooms, the usual sites for these activities, are not notable for the privacy they afford. $I d$. at 657.

159. Oliver, 466 U.S. at 178 (citing United States v. Chadwick, 433 U.S. 1, 7-8 (1977); Jones v. United States, 362 U.S. 257, 265 (1960)). See also Boyd v. United States, 116 U.S. 616, 630 (1886) (emphasizing the "sanctity of a man's home and the privacies of life").

160. Oliver, 466 U.S. at 179.

161. Id.

162. $I d$.

163. See, e.g., Orin S. Kerr, The Fourth Amendment and New Technologies: Constitutional Myths and the Case for Caution, 102 MicH. L. REV. 801, 814 (2004) ("Whereas a search occurs when government action violates a defendant's reasonable expectation of privacy, a seizure occurs only when the government action causes a "meaningful interference with an individual's possessory interests in . . . property").

164. Smith v. Maryland, 442 U.S. 735, 749 (1979) (Marshall, J., dissenting); see also United States v. Jones, 132 S. Ct. 945 (2012) (holding that the use of a GPS tracking device to monitor a suspect's movements for 
the Fourth Amendment, the Court has rejected what it has embraced under the free exercise clause: case-by-case decision-making that fails to strike a meaningful balance between religious liberty and secular governmental interests. In Oliver, the Court explained that this approach would not "provide a workable accommodation between the needs of law enforcement and the interests protected by the Fourth Amendment." 165 Police officers would be required "to guess before every search whether landowners had erected fences sufficiently high, posted a sufficient number of warning signs, or located contraband in an area sufficiently secluded to establish a right of privacy." 166 As such, "[t]he lawfulness of a search would turn on "'[a] highly sophisticated set of rules, qualified by all sorts of ifs, ands, and buts and requiring the drawing of subtle nuances and hairline distinctions.",167

The Court should adopt a similar approach when interpreting the free exercise clause, thus recognizing that religious freedom is inextricably linked to the societal contexts in which it is expressed. In fact, several themes have emerged from the Court's free exercise jurisprudence, many of which lay the groundwork for developing a more cohesive approach to protecting religious liberty while also respecting the government's authority to advance important state and federal interests. The Court's decisions focus primarily on the following four factors:

- Whether the law applies in a public, quasi-public, or private area;

- Whether the law compels or prohibits behavior;

- Whether the law targets specific religions or practices, or applies equally to all citizens; and

- Whether the law regulates beliefs or practices.

In cases like Goldman, Lyng, and Smith, the Court relied in part on these factors to uphold laws that interfered with religious liberty. As evident in Burwell, however, the Court has not always embraced this interpretation of the free exercise clause and the result has been a muddled jurisprudence under the free exercise clause.

As discussed below, the Court can bring cohesion to free exercise disputes by adopting the approach used in Fourth Amendment cases, where factors such as the place in which the privacy interest is asserted, the items or objects searched, and the countervailing needs of law enforcement, determine the strength of a privacy claim and the burdens on law enforcement. Simply put, the higher a privacy valuation, the higher the burden on law enforcement. This approach has resulted in principled, albeit imperfect, distinctions between private, quasi-public, and public space, and reflect pragmatic considerations to ensure that law enforcement investigatory authority is not frustrated by unrealistic standards. For example, Fourth Amendment protections apply with less force when "special needs, beyond the normal need for law enforcement, make the

twenty-eight days violated the Fourth Amendment).

165. Oliver, 466 U.S. at 181. (quoting New York v. Belton, 453 U.S. 454, 458 (1981)) (quoting LaFave, “Case-By-Case Adjudication” versus "Standardized Procedures”: The Robinson Dilemma, 1974 S. CT. REV. 127,142 (1974)).

165. Oliver, 466 U.S. at 181.

166. Id.

167. Id. 
warrant and probable-cause requirement impracticable." "168 In such circumstances, "balance[s] the governmental and privacy interests to assess the practicality of the warrant and probable-cause requirements in the particular context." ${ }^{\prime 169}$ Furthermore, the government's interest in warrantless searches is most compelling when the "the burden of obtaining a warrant is likely to frustrate the governmental purpose behind the search."

Practicality and purpose are precisely what the Court's free exercise jurisprudence lacks. The Court assesses a law interfering with free exercise rights by examining its effect on religious beliefs and practices, but the determination of whether an effect is incidental or substantial depends on the degree to which that right is protected in a given context. For example, when interpreting the Fourth Amendment, the Court has held that law enforcement need only have reasonable suspicion before stopping a motorist because the right to privacy is reduced in quasipublic spaces, thus rendering the interference with a motorist's privacy less substantial. At the same time, law enforcement could never search a home with merely reasonable suspicion because privacy rights engender more protections in private spaces. This approach inherently — and effectively — balances privacy rights against the societal interests in crime prevention and public safety. In free exercise cases, there is no valuation of religious liberty, which has led the Court to invalidate laws that advance important government interests and that place little, if any, burden on an individual's religious beliefs or practices.

This was exemplified in Burwell, when the Court exempted a closely-held corporation from a law that had no impact on the petitioners' right to freely exercise their religion, advanced compelling governmental interests, and applied only to public entities that were responsible for providing their employees with health insurance. If this approach were used when deciding Fourth Amendment disputes, such that any infringements on privacy always required probable cause and a warrant, then law enforcement's ability to prevent and investigate criminal conduct would be severely undermined. That, in a nutshell, is the point.

The above discussion is not meant to suggest that there are no similarities in the adjudication of Fourth Amendment and free exercise cases. In both areas, the Court conducts a balancing test that weighs individual rights against societal and governmental interests. The difference is that an individual's right to privacy is not given the highest levels of protection in all contexts.171 This is not true, or is less

168. Skinner, 489 U.S. at 619 (quoting Griffin v. Wisconsin, 483 U.S. 868, 873 (1987)) (citation omitted).

169. Id. (quoting Bell v. Wolfish, 441 U.S. 520, 558-560 (1979)) (permitting body cavity searches of prison inmates) (emphasis added).

170. Id. at 623 (citation omitted).

171. Stern, supra note 153, at 920-21. Of course, this is not to say that the Court's Fourth Amendment jurisprudence is perfect, or that it adequately protects privacy rights. One commentator states as follows:

Judicial doctrine and rhetoric constructing the home as a psychological and political fortress have created a strikingly inconsistent, and at times bizarre, pattern of privacy protection ... Privacy interests must be prioritized and balanced against other societal needs, such as safety, crime control, and judicial and governmental resources. The current patchwork of Fourth Amendment search protection does not strike an appropriate balance: in its permutations in various search contextsresidence, curtilage, garbage, and nonresidential-it overprotects and underprotects with respect to intrusiveness and harm... Rather than allocating privacy on the basis of intrusiveness, objective 
true, when free exercise disputes arise. In the Fourth Amendment context, it would be akin to affording privacy the highest level of protection regardless of whether a citizen is sleeping at home, driving a car, or standing in an open field. Not surprisingly, this is precisely the problem that has occurred in recent free exercise cases. The heightened protection afforded to religious liberty in all cases requires the government to satisfy strict scrutiny, even where the law at issue applies only in public spaces and neither compels nor prohibits an individual from practicing their religious faith or expressing their beliefs. 172 The result has been an over-protection of religious liberty and an under-valuing of all citizens' right to equal and nondiscriminatory treatment in the public domain. Unfortunately, a skewed balancing test produces unjust outcomes, as the Court's decision in Hobby Lobby demonstrated.

The Table below offers a new interpretive model to more effectively balance religious liberty claims against countervailing governmental interests.

harm, and societal interests ... courts have typically opted to allocate based on context or publicity.

172. See, e.g., Burwell, 134 S. Ct. 2751. 


\section{Table III}

A Balanced Approach to the Free Exercise Clause

\begin{tabular}{|c|c|c|c|c|}
\hline $\begin{array}{l}\text { Type of } \\
\text { Expression }\end{array}$ & $\begin{array}{l}\text { Nature of } \\
\text { Law }\end{array}$ & Context & Standard & Permissible Laws \\
\hline $\begin{array}{l}\text { Religious } \\
\text { Beliefs }\end{array}$ & $\begin{array}{l}\text { Laws } \\
\text { Compelling } \\
\text { or } \\
\text { Prohibiting } \\
\text { Conduct }\end{array}$ & $\begin{array}{l}\text { Private, } \\
\text { Public, and } \\
\text { Quasi- } \\
\text { Public } \\
\text { Areas }\end{array}$ & $\begin{array}{l}\text { Compelling } \\
\text { State Interest } \\
\text { and Narrow } \\
\text { Tailoring }\end{array}$ & $\begin{array}{l}\text { Prohibiting } \\
\text { parents, in limited } \\
\text { circumstances, } \\
\text { from refusing } \\
\text { conventional } \\
\text { medical treatment } \\
\text { for their children }\end{array}$ \\
\hline $\begin{array}{l}\text { Religious } \\
\text { Practices }\end{array}$ & $\begin{array}{l}\text { Laws } \\
\text { Compelling } \\
\text { or } \\
\text { Prohibiting } \\
\text { Conduct }\end{array}$ & $\begin{array}{l}\text { Private } \\
\text { Areas }\end{array}$ & $\begin{array}{l}\text { Compelling } \\
\text { State Interest } \\
\text { and Narrow } \\
\text { Tailoring }\end{array}$ & $\begin{array}{l}\text { Laws prohibiting } \\
\text { the ritual slaughter } \\
\text { of animals } \\
\text { provided they do } \\
\text { not target a } \\
\text { specific religion }\end{array}$ \\
\hline $\begin{array}{l}\text { Religious } \\
\text { Practices }\end{array}$ & $\begin{array}{l}\text { Laws } \\
\text { Compelling } \\
\text { or } \\
\text { Prohibiting } \\
\text { Conduct }\end{array}$ & $\begin{array}{l}\text { Quasi- } \\
\text { Public } \\
\text { Areas }\end{array}$ & $\begin{array}{l}\text { Substantial } \\
\text { Governmental } \\
\text { Interest that } \\
\text { Burdens } \\
\text { Religious } \\
\text { Practices No } \\
\text { More than } \\
\text { Necessary to } \\
\text { Achieve the } \\
\text { Asserted } \\
\text { Interest }\end{array}$ & $\begin{array}{l}\text { Laws prohibiting } \\
\text { the use of } \\
\text { controlled or } \\
\text { illegal substances } \\
\text { (Employment } \\
\text { Division v. Smith) }\end{array}$ \\
\hline $\begin{array}{l}\text { Religious } \\
\text { Practices } \\
\text { and Beliefs }\end{array}$ & $\begin{array}{l}\text { Laws } \\
\text { Prohibiting } \\
\text { Conduct }\end{array}$ & $\begin{array}{l}\text { Public and } \\
\text { Areas that } \\
\text { Involve } \\
\text { Service to } \\
\text { or } \\
\text { Accommod } \\
\text { ation of the } \\
\text { Public, or } \\
\text { Implicate } \\
\text { Public } \\
\text { Health, } \\
\text { Safety, and } \\
\text { Welfare }\end{array}$ & $\begin{array}{l}\text { Rational, } \\
\text { Secular } \\
\text { Government } \\
\text { Interest that } \\
\text { Does Not } \\
\text { Target or } \\
\text { Disproportion } \\
\text { ately Impact a } \\
\text { Particular } \\
\text { Religion }\end{array}$ & $\begin{array}{l}\text { Anti- } \\
\text { discrimination } \\
\text { laws (race, } \\
\text { ethnicity, gender, } \\
\text { socio-economic } \\
\text { status, sexual } \\
\text { orientation) }\end{array}$ \\
\hline
\end{tabular}

Ultimately, the First Congress drafted the free exercise clause with a view that 
liberty cannot be fully realized if the government adopts a position or endorses a particular view on matters of personal conscience and faith. When government expresses a preference, however slight, for certain religions or religious practices, citizens are implicitly discouraged from developing their own. The Court's recent decisions do not reflect the purpose and meaning of the free exercise clause, which was to protect religion against governmental persecution or coercion, not to permit individual religious beliefs to trump laws advancing the collective interests of all citizens.

\section{CONCLUSION}

Constitutional rights are not absolute rights, and the free exercise of religion is no more sacred than an individual's right to be free from unreasonable searches and seizures. The best approach is to recognize that the right to freely exercise one's religion is, at its core, a guarantee of personal autonomy. It is a promise that the government will neither endorse nor punish citizens for exercising their religious beliefs, but instead cultivate a climate where citizens of diverse backgrounds can express and practice their beliefs while being treated equally under the law. At the same time, the free exercise clause does not absolve citizens of the responsibility to comply with laws that advance the collective interests of all citizens, neither punish nor target specific religions, and prohibit rather than compel conduct that, in itself, is purely secular. Simply stated, the free exercise clause is a shield against government coercion, not a license for individuals to avoid complying with laws that advance important societal interests and promote equality for all citizens. 